\title{
Triple Bottom Line in Indonesia Commercial Palm Oil Mill Business: Analytical Network Process Approach
}

\author{
Arif Imam Suroso ${ }^{1 *}$, Iyung Pahan ${ }^{2}$, Hansen Tandra ${ }^{3}$ \\ ${ }^{1}$ School of Business, IPB University, Bogor 16151, Indonesia \\ ${ }^{2}$ DMI Consulting Firm, Jakarta 12930, Indonesia \\ ${ }^{3}$ Department of Environmental and Resources Economics, IPB University, Bogor 16680, Indonesia
}

Corresponding Author Email: arifimamsuroso@apps.ipb.ac.id

https://doi.org/10.18280/ijsdp.160517

Received: 4 June 2021

Accepted: 30 July 2021

\section{Keywords:}

analytic network process, triple bottom

line, palm oil, business, sustainable development

\begin{abstract}
The latest trend in palm oil business is the emergence of independent commercial crude palm oil (CPO) mills, which emphasize processing FFB from smallholder plantations. The involvement of smallholders without mill in CPO operations shows that there is potential from the business for sustainable development. The purpose of this study to investigate the Indonesian commercial CPO mill business with a triple bottom line perspective. Moreover, this is to gain how much benefit the Commercial CPO mill business is in terms of profit, people and planet. This study applied the Analytic Network Process (ANP) with the criteria of profitability, social justice and environmental quality. This analytical technique uses a number of experts related to the palm oil business and sustainable development. The results of this study reveal that the critical success factors of priority Indonesian commercial CPO mills are the source of raw materials from small farmers $(71.90 \%)$ and operational considerations of CPO mills $(28.10 \%)$. While the benefits of this business can create shared value through quadruple helix analysis of academics, entrepreneurs, communities, and government which ranks profit $(53.05 \%)$, people $(23.75 \%)$ and planet $(23.19 \%)$. The significant results of this study revealed that the Indonesia Commercial CPO mill is sustainable from triple bottom line point of view.
\end{abstract}

\section{INTRODUCTION}

Indonesia palm oil business has grown rapidly and took over the first ranked as the biggest global producer since 2004 [1, 2 ], and has been reported very competitive both in firm level and also on a country level $[3,4]$. The development of palm oil business can be used as an effort by governments to generate foreign exchange, enlarge job creation, and improve farmers welfare [5, 6]. Indonesia oil palm plantation in 2018 has achieved approximately more than 12 million hectares planted area as shown in Figure 1 [7]. The most significant upward trend was big private companies and smallholders, while smallholders will take over the majority portion in a couple years. Based on this condition, the role of Indonesia palm oil stakeholders in the near future will change fundamentally, with respect to public empowerment and environmental aspect [8]. The oil palm economy can be used as a vehicle to contribute positively for rural poverty eradication and economic development [9]. It is also can be used as a model for other countries with similar soils, climate, labor availability, and also a showcase for environmental improvement [10]. The oil palm-based industry has contributed to Indonesia economic growth, poverty alleviation, and income equity improvement $[11,12]$. The economic, social and environmental approach, formulated by Elkington [13] as triple bottom line concept, is commonly referred as triple bottom line (profit, people, and planet) which became mainstream for business sustainability as effort to integrate economic, environmental and social considerations into a company's appraisal and decision-making actions [14]. Furthermore, triple bottom line can improve well-being and quality of life through the creation of jobs and wealth including creation, extension, retention, and employment, of jobs and businesses [15]. It will reach to the overall goal of sustainable development which is a long-term stability of economic and environment. Commonly, the basic concept of sustainable development based on United Nations Assembly [16] is "development that meets the needs of the present without compromising the ability of future generations to meet their own needs" [17]. Specifically, the sustainable development can be defined as a reconciliation of the economy and the environment to being a new path for long-term development in future $[18,19]$.

The palm oil industry is exposed to global vegetable oil trade competition and facing a lot of international pressure through negative publication and intense mediatization. Media attacks palm oil industry through conventional media and nongovernment organization [20], and social media publics [21]. Specifically, these issues about palm oil controversies concern to impact of palm oil production on tropical peatland and their relation in global palm oil consumption [22]. However, palm oil is the most traded vegetable oil in the world, exceeding other vegetable oils and transformed Indonesia became the global main producer. This study is aimed to identify how the triple bottom line concept influences the Indonesia commercial palm oil business and its implications on creating 
shared value for the sustainability of the entire business.

This study also disagrees with "oil palm complex" terminology, introduced by McCarthy and Cramb [23] as a process of "complexation" of different actors with varying interest and capabilities within the constraints set by the broader political economy, in the process creating a recognizable pattern with the distinct outcome. This terminology created controversies among palm oil stakeholders, the "complex of the oil palm" skews the allocation of resources and benefit distribution in support of a capable cross-country coalition of political, bureaucratic, and agribusiness interest that, notwithstanding the industry rhetoric, puts "profit" well ahead of "people" or "planet". This thesis differs with Porter and Kramer [24] and Porter [25] that emphasized on creating shared value through "profit" and redeploying scalable resources to solve "people" and "planet" issues. Moreover, the palm oil industry activities have led to several debates on environmental issues such as pollution, land-use change, deforestation [26, 27] and social conflict [28]. This will force a change in the business model of the palm oil industry.

In the next couple of years, Indonesia palm oil industry will change as the implication of vast development of public smallholder planting area that will bigger than private/SOE plantation [8]. Smallholders and its additional feedstock should be covered by the additional crude palm oil (CPO) milling capacity through commercial CPO mill scheme. This condition is changing from traditional business model which is run by big private companies and SOEs to commercial CPO mill which is run by the joint venture of smallholder cooperatives and new players. It needs sustainable processing cooperation on new CPO mill erection, so the smallholders can get dual income both from fresh fruit bunch (FFB) selling as well mill profit sharing.

The problems of commercial CPO mill are feedstock availability in enough to support milling installed capacity and make it profitable. The organization should prosper first before it can create wealth and benefits for the entire system. Palm oil business profit could solve social and environmental problems through resources deployment and leveraging social justice (people) and living environment (planet) to expected levels.
Profitability is a starting point and the mechanism to make the entire model a sustainable business. In short, the organization must make a profit first before the organization can pay attention to social issues and the environment [25]. Commercial CPO mill business sustainability is referred to profit generation, social justice in term of income distribution among stakeholders, and environmental handling improvement. Milling capacity adequacy is a key ingredient to produce profit, and the availability of adequate CPO mill is a must. Without additional CPO milling, the additional feedstock from smallholders cannot be absorbed and process properly to produce added value.

There are many literatures discussed the sustainable development in palm oil industry and the implication for environment and social aspects. Laurance et al. [29] were examined about Improvement the Performance of Palm Oil Industry based on Roundtable on Sustainable Palm Oil (RSPO) for Environment, especially Nature Conservation. The findings shown the expansion of oil plam plantations affecting the climates and destroying the forest, so the RSPO needs to expand a real controlling and takes a stronger position for stand against forest destruction. The expansion of palm oil plantations must be balanced with zero deforestation policies and prohibition of peatland conversion for reach the sustainable development goals [30]. Carlson et al. [31] studied that palm oil sustainability certification could reduce deforestation and fire rates by comparing the certified plantations and non-certified plantations. Moreover, the oil palm plantations could implicate the domestic issue such as social conflicts around land access and yield differences [32]. These issues are also highlight to sustainable development as a integration of people, planet and profit in oil palm industry especially plantations. However, an alternative business model such as Commercial CPO mill without plantations is rare to investigated. This is the main reason in this study to revealed how to be sustainable in this latest trend in oil palm business model. With recent global palm oil industry circumstance is under attacked condition by many negative campaigns related to environmental issues, the research question in term of the triple bottom line: Is Indonesia commercial CPO mill business sustainable?

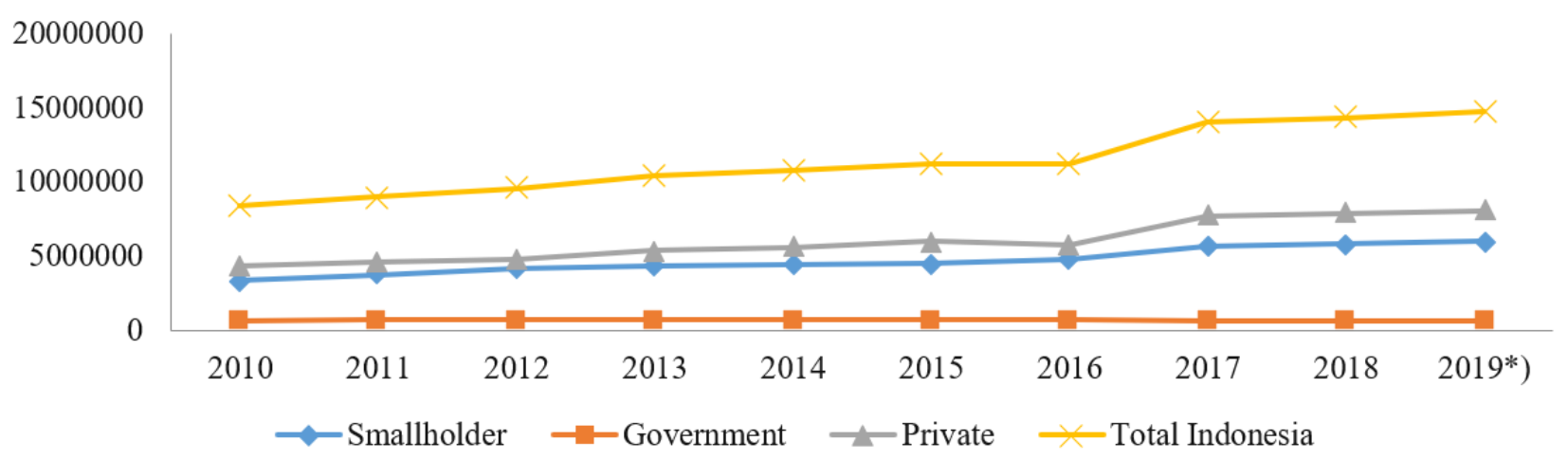

Figure 1. Indonesia oil palm planted area [7]

\section{METHOD}

This research used cross-section data in the form of experts and/or practitioner's perception. Data sources used were primary data collected specifically through expert's validation (for the conceptual framework) and close-ended questionnaires filling survey (for research result). Analysis unit of research was a case study in the biggest province of Indonesian oil palm producer that is Riau which represented an industrial agglomeration of $20.96 \%$ of the Indonesian oil palm plantation area [1]. Data collection was accomplished through questionnaire filling survey by using ANP tools. 
Respondents were 10 experts and/or practitioners selected with purposive sampling method from the whole stakeholders of Indonesian palm oil industry, which represented of academician $(n=3)$, the business player $(n=3)$, community (farmer cooperative, as well non-government organization, $\mathrm{n}=2)$, and government officer $(\mathrm{n}=2)$.

Research variables measurement was developed from the palm oil industry expert's conceptual framework of (1) Feedstock source, and (2) Commercial CPO mill operation. New commercial CPO mill erection should be calculated precisely and sustainably in triple bottom line concept of profit-people-planet (3-p), i.e.: profitability in economic side, fair income distribution in people side, as well the living environment in planet side as pronounced by Elkington [13]. Conceptual thinking framework in this study is developed to build sustainable Indonesia commercial CPO mill (Figure 2) consist of feedstock sources, and commercial CPO mill operation in term of the triple bottom line. Conceptual thinking framework is developed to answer the research question. The concept is decomposed and formulated from the following sources: Agriculture Ministry, [33]; James et al. [34]; Pahan et al. [8]; Pahan, [1] and validated to experts through an expert's validation. Feedstock source consider three nodes of Indonesia palm oil players, namely SOEs, big private companies, and smallholders. The most dominant hectarage at this moment are big private companies, smallholders, and SOEs. The oil palm composition area within the next couple years will change and smallholder will take a lead as a majority $[1,8]$. Commercial CPO mill operation considers three nodes of triple bottom line referred as three-Ps (profit, people and planet) [13, 35]. Profit [25] is the economic capability to get a net margin on whatever business solution has ever created to whatever problem they're trying to solve. People are a fair income distribution among palm oil business stakeholders includes the company's impact on its employees and the social system within its community [36]. The planet is living environmental consideration when operate the commercial CPO mill to notice at the qualitative and quantitative impacts that they are having on their local, national and international resources [36].

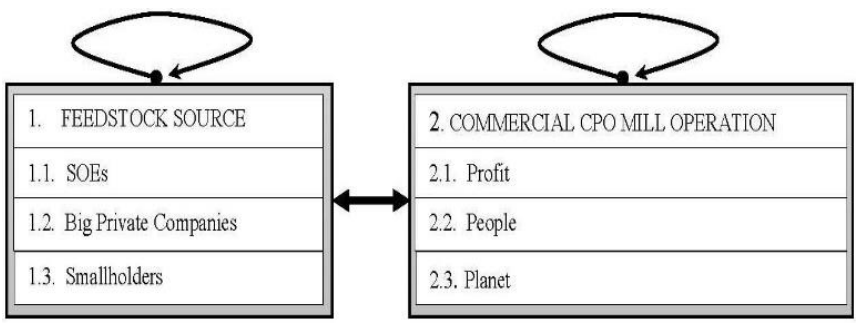

Figure 2. Research conceptual framework

The research methods is using analytic network process (ANP) as developed by Saaty [37]. ANP is a multi-criteria decision analysis that uses a system of pairwise comparisons to measure the weights of the components of the structure, and finally, to rank the alternatives in the decisions. ANP is the non-Bayesian, non-parametric qualitative approach for decision-making with a common framework without assumptions. ANP could seize feedback effect, combined tangible and intangible values, and create a positive or negative influenced indicators that could be weighted and compared. ANP requires the description of a decision network comprising indicators and clusters to link each other between indicators and clusters [38]. The major difference between ANP and AHP in analysis structure which ANP models interdependencies using a feedback structure among clusters of a network $[39,40]$. The concept of AHP and ANP are shown in Figure 3 and Figure 4.

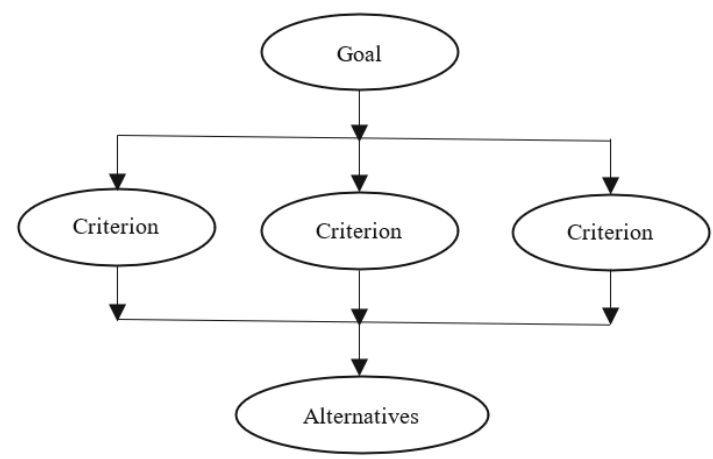

Figure 3. Hierarchy structure (AHP)

The main step developments are (1) Model construction, (2) Model quantification, and (3) Results analysis [37, 41]. However, the specific step of ANP involves the following steps [38-40].

1. Build the decision network model by elaborate the ranking problem into a hierarchy with three main cluster such as goal clusters, criteria clusters and alternatives cluster.

2. Develop the pairwise comparison matrix $A=\left[a_{i j}\right]$ for all clusters and indicators in square matrix form. The pairwise comparison lattice $\mathrm{P}$ may be a squared complementary conclusion positive framework in which its non-specific term $p_{i, j}$ break even with to 1 for $i=j$ and $\mathrm{p}_{\mathrm{i}, \mathrm{j}}=1 / \mathrm{p}_{\mathrm{j}, \mathrm{i}}$ for $\mathrm{i} \neq$ indicates the relative significance of the calculate $i$ against the figure $j$ with regard to the objective. For the pairwise comparisons of components, the wellknown 9 point Saaty assessment scale is received. This requires that the array of object to be compared pairwise must be homogenous. Specifically, the greatest object's dominance must be no more than 9 times that of the smallest [42].

3. Count relative crititcal weights of the indicators called wij to develop a Relative Value Vector (RVV) in the relevant matrix. Wij can counted via the Eq. (1) as below reported:

$$
W i j=\frac{\sum_{j=1}^{n}\left(\frac{p i, j}{\sum_{i=1}^{n} P i, j}\right)}{n}, \forall \mathrm{i}, \mathrm{j}=1,2 \ldots \mathrm{n}
$$

The particular eigenvalue $\lambda_{\max }$ to look at the consistency of the scaled decision is gotten through the taking after Eq. (2):

$$
\left(\mathrm{A}_{\mathrm{m}} \times \mathrm{m}\right)\left(\mathrm{W}_{\mathrm{m}} \times 1\right)=\left(\lambda_{\max }\right)\left(\mathrm{w}_{\mathrm{m}} \times 1\right)
$$

4. Evaluate consistency of the pairwise comparison matrix $P$ based on Consistency Index (CI) and Consistency Ratio (CR). The CI and CR values are obtained through the following Eq. (3) and Eq. (4):

$$
\begin{gathered}
\mathrm{CI}=\left(\lambda_{\max }-\mathrm{n}\right) /(\mathrm{n}-1) \\
\mathrm{CR}=\mathrm{CI} / \mathrm{RI}
\end{gathered}
$$

5. Where nis the number of components within the decision framework and Random Index (RI) based on Saaty RI Value [34]. RI Value is obtained by the compared number of elements $\mathrm{n}$ is equal to $2,3,8$ and equal to $0.00 ; 0.58$; 
$0.90 ; 1.12 ; 1.24 ; 1.32 ; 1.41$, respectively. If $\mathrm{CR}<0.1$, then the comparison matrix is considered to be consistent enough for proceeding otherwise the comparison matrix should be improved.

6. Establish a super-matrix by interview with selected experts and synthesizing the RVVs. A definition of super matrix is Apportioned network in which each sub-matrix comprises of connections between two clusters. Commonly, it is unweighted that must be converted into the weighted super matrix.

7. The weighted super-matrix is raised to be limiting powers until the weights merge to steady values, in this way shaping the limit super-matrix which contain the weights and priorities of factors concerning the considered alternatives are discovered.

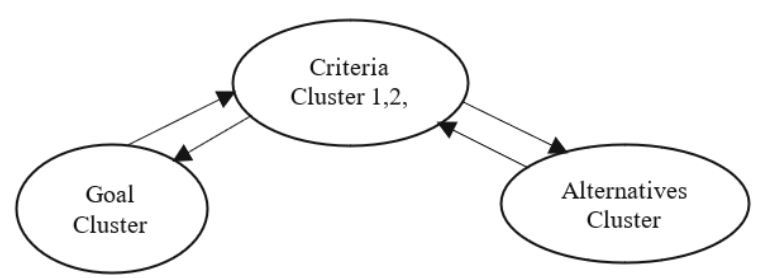

Figure 4. Decision network models (ANP)

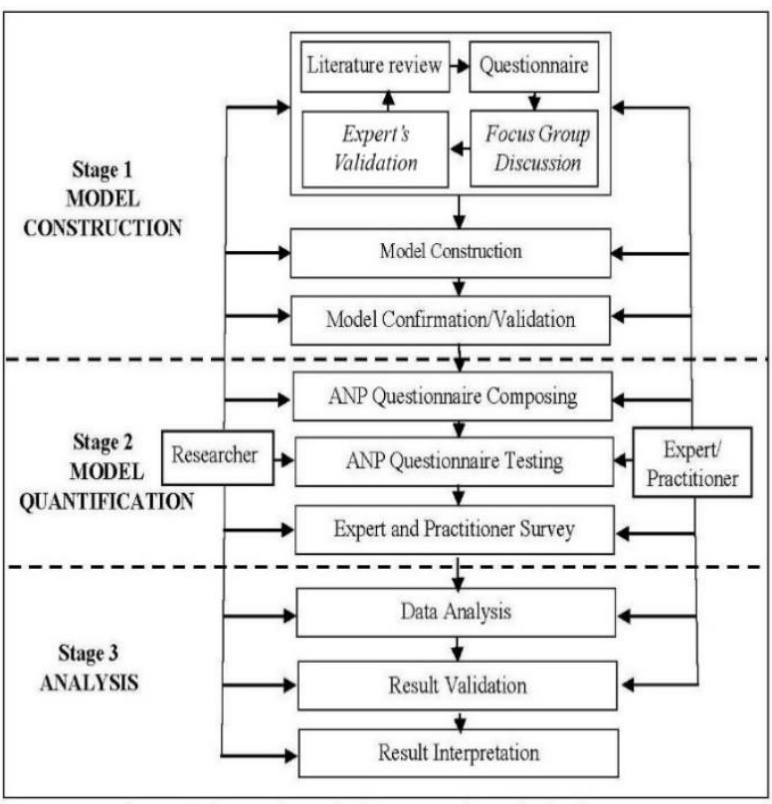

Figure 5. Research stage

Based on common stage of ANP, there are three-stage are developed in this research, namely model construction, model quantification and analysis stage (Figure 5). Decomposition stage is a problem understanding through a theoretical based, literature review, questionnaire, focus group discussions, and expert's validation. Decomposition or analysis is the way in structuring problem complexity into ANP framework. Assessment stage is done with designing a questionnaire and pairwise comparison survey. Synthesis and analysis stage is carried out with data processing and synthesis using ANP software (Super Decisions), and analyses the results as unweighted, weighted and limiting super-matrix priority.

By using ANP software Super Decisions, data processing was done. ANP did not qualify data sufficiency, but the respondents had to be experts or mastery in the problem being analyzed. Questionnaire simplification in ANP was done to improve consistency and to make an easier survey for both interviewers and respondents. Maximum consistency ratio (CR) value which could be tolerated was less than $10 \%$ [37, 41]. Quality of experts and practitioner's opinion in this study were analyzed using rater agreement which showed the level of respondent's concordance $\left(\mathrm{R}_{1}-\mathrm{R}_{\mathrm{n}}\right)$ to an issue in a cluster. Kendall's coefficient of concordance (notation as W, with value ranged from 0-1) was one of the instruments to measure valuer agreement. $\mathrm{W}$ value as one showed perfect concordance [43].

\section{RESULTS AND DISCUSSION}

Based on Indonesia palm oil expert perspective, key success factors of commercial CPO mill were determined $71.90 \%$ by feedstock sources availability, and $28.10 \%$ by commercial CPO mill operation considerations (Table 1). The main priority of feedstock sources were smallholders $(43.70 \%)$ and the main commercial CPO mill operation was profit (14.91\%). Feedstock availability from smallholders and high profitability of commercial CPO mill operation are the key success factors for business sustainability. This study was carried out with streamlined questionnaire to reduce inconsistency and successfully reach consistency ratio (CR) $0.002 \%$. It means that the matrix comparison of the ANP model is good and consistent with $\mathrm{CR}$ value below $10 \%$. The quality of data which represents opinion commonality of the Indonesia palm oil experts and practitioners in this study are analyzed with Kendall's coefficient of concordance (given notation as W) with the value 0.8331 . This situation reflected the normative thinking on the sustainable business which gives more similar perception due to the commonality context at every chain of quadruple helix represented by the respondent affiliation. All parties academician, businessman, community, and government have the same opinion on the importance of feedstock source aspect compared to the commercial CPO mill operation.

The joint venture of smallholders and new player to build commercial CPO mill business is the vehicle of smallholder resurgence whereas they can get included in the positive terms of palm oil economy (profit) with weight 14.91\%. Smallholders will get dual income from FFB selling, as well palm oil mill profit sharing. Fair income distribution among stakeholders (people) and living environment (planet) consideration are also important for commercial CPO mill business in Indonesia (especially Riau) with weight priority $6.68 \%$ and $6.52 \%$ respectively (Table 1 ). New palm oil mill erection become the incentive for the smallholders as long as it is building nearby the massive smallholder pockets area and not so near with existing big private plantation companies. The commercial CPO mill scheme above which is joint venture between smallholders and new player to build commercial CPO mill creates a strong bond among smallholders and new investors to strengthen the oil palm smallholder bargaining position. This strong position impacts positively on the entire Indonesia palm oil industry and provides some positive notes for the gloomy "oil palm complex" terminology [44]. The future of Indonesia palm oil industry is no longer regulated and determined by political compromises that set the context for institutional and other policies [45]. Its lead condition encompasses the key opportunities for surplus extraction and not just political patronage across the region. Single bottom 
line plus vague commitment to social and environmental interest will evolve and transform become harmonious relationship among profit, people and planet as a full pledge triple bottom line [46-48] with profit as starting point to create shared value which mobilizes resources to address social and environmental problems [24, 25]. The implementation of triple bottom line in manufacturing industry can provide significantly in organizational attractiveness ratings which implicate on higher firm performance in long term [49].

There were five common steps in which company (included palm oil business) can make their practices more sustainable and responsible for their action: (1) defensive, (2) deal with compliance, (3) incorporate mindset into its activities, (4) strategic and providing "a leg up" on the competition and strive to achieve it because of these advantages, and (5) final stage of corporate sustainability on civil stage where company will hallmark the shared value of their products or practices [50]. Creating palm oil business shared value is addressing social and environmental issues with the business model, whereas shared value creates social values and economic values simultaneously through the scalability to create resources. Only business can establish resources, other institutions could just apply them to do essential work. Shared value proposition comes from intersection of change how palm oil business sees itself and change how others see palm oil business [24, 25] with respect to harmonious full pledge triple bottom line [34, 47, 48].
Academicians, business players, communities and government (quadruple helix) have many issues in which it could impact the willingness and the ability to compete in making shared value become a reality (Figure 6). Involvement between actors can measure the extent to which the business model of commercial CPO mills can achieve sustainable goals in the palm oil industry. These actors must jointly play their roles optimally to help this business model achieve its sustainable goals. Academics as intellectual actors need help from businessmen to carry out their creations. Communities are people who feel the impact from the business model that is run. Meanwhile, the government must be able to create safe and conducive business conditions through regulations. Shared value is the intersection of the way how palm oil business sees itself and how others see palm oil business [25], along with a conventional economic development mindset that underscore to economic growth over social equity and environmental shelter [15]. All parties of academician, business, communities and government aggregation (normalized by cluster) are put profit $(53.05 \%)$ as more important than people $(23.75 \%)$ and the planet $(23.19 \%)$ as shown in Table 1. The overall stakeholders affiliation which ranked profit as main priority respectively are government, businessman, communities, and academician. Among stakeholders who are most concerned about the importance of income distribution aspect (people) are respectively government, businessman, academician, and communities.

Table 1. Priority of commercial CPO mill

\begin{tabular}{|c|c|c|c|c|c|c|}
\hline \multirow[t]{2}{*}{ Name } & \multicolumn{5}{|c|}{ Limiting Super-Matrix by } & \multirow[b]{2}{*}{ Normalized by Cluster } \\
\hline & Academician & Businessman & Community & Government & All ABCG & \\
\hline \multicolumn{7}{|l|}{ FEEDSTOCK SOURCE } \\
\hline $1.1 \mathrm{SOEs}$ & $9.41 \%$ & $10.46 \%$ & $7.12 \%$ & $11.61 \%$ & $9.74 \%$ & $13.54 \%$ \\
\hline 1.2 Privates & $17.04 \%$ & $20.74 \%$ & $21.70 \%$ & $13.6 \%$ & $18.47 \%$ & $25.68 \%$ \\
\hline 1.3 Smallholders & $48.59 \%$ & $37.16 \%$ & $50.52 \%$ & $37.98 \%$ & $43.70 \%$ & $60.78 \%$ \\
\hline Subtotal & $75.05 \%$ & $68.36 \%$ & $79.34 \%$ & $63.35 \%$ & $71.90 \%$ & $100.00 \%$ \\
\hline \multicolumn{7}{|l|}{ COMM. CPO MILL OPERATION } \\
\hline 2.1 Profit & $12.58 \%$ & $16.56 \%$ & $12.21 \%$ & $19.70 \%$ & $14.91 \%$ & $53.05 \%$ \\
\hline 2.2 People & $6.57 \%$ & $6.80 \%$ & $5.16 \%$ & $7.95 \%$ & $6.68 \%$ & $23.75 \%$ \\
\hline 2.3 Planet & $5.53 \%$ & $9.27 \%$ & $3.28 \%$ & $9.00 \%$ & $6.52 \%$ & $23.19 \%$ \\
\hline Subtotal & $24.95 \%$ & $31.64 \%$ & $20.66 \%$ & $36.65 \%$ & $28.10 \%$ & $100.00 \%$ \\
\hline TOTAL & $100.00 \%$ & $100.00 \%$ & $100.00 \%$ & $100.00 \%$ & $100.00 \%$ & \\
\hline \multicolumn{7}{|l|}{ NOTES } \\
\hline 4.1 Total respondent (n) & 3 & 3 & 2 & 2 & 10 & \\
\hline 4.2 CR (Consistency ratio) & $0.004 \%$ & $0.001 \%$ & $0.006 \%$ & $0.000 \%$ & $0.002 \%$ & \\
\hline 4.3 W (Kendall's Concordance) & 0.8476 & 0.9365 & 0.9714 & 0.9714 & 0.8331 & \\
\hline $4.4 \mathrm{p}$-value of $\mathrm{W}$ & 0.0017 & 0.0009 & 0.0018 & 0.0018 & 0.0000 & \\
\hline
\end{tabular}

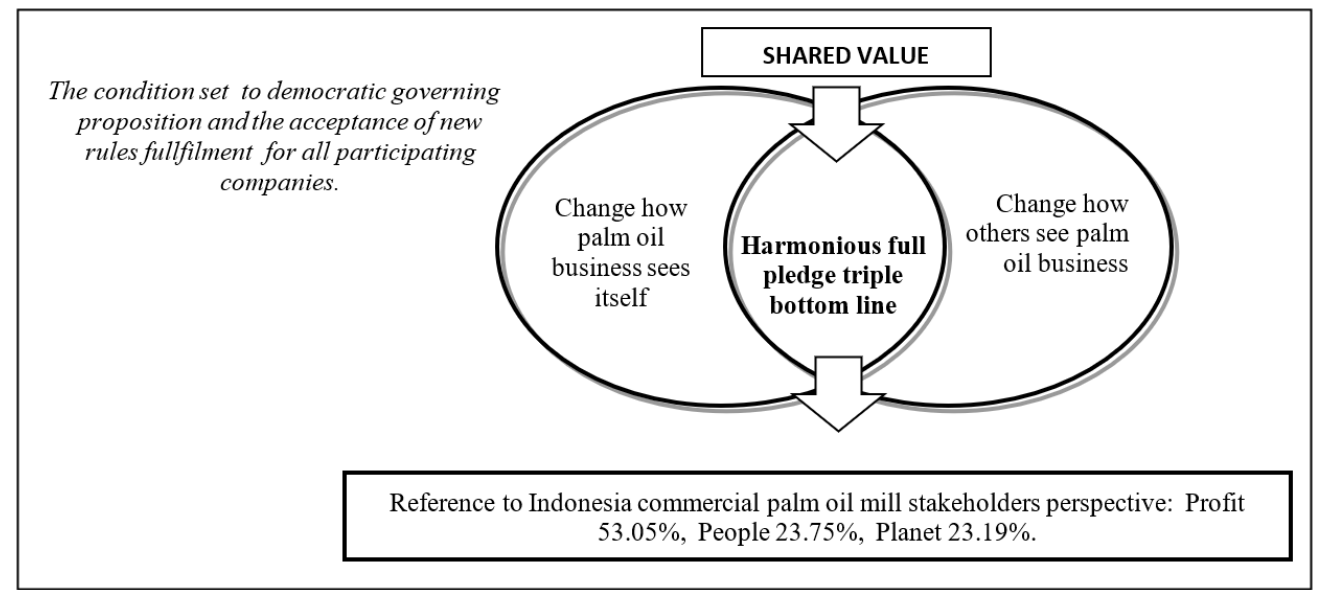

Figure 6. Commercial CPO mill business shared value $[20,21,51]$ 
As for the aspects of the living environment (planet) in the commercial CPO mill operation which considers this important factor are respectively businessman, government, academician and communities. There is a common reason that business entities shall put profit priority in front of people and planet due to their liability to deploy some part of the profit to solve social and environmental issues. Triple bottom line could be overlap and conflict each other dimensions, so it must need to be holistic to implement all of them $[51,52]$. However, commercial CPO mill business is still beneficial based on the harmonious triple bottom line with profit weighted more than twice than people and planet. This statement strengthens the shared value concept of Porter and Kramer (2011) and Porter (2013) that resources were created from business profit [24, 25]. However, these results reveals an assessment for alternative business model as a counterfeit the environmental and social issues in palm oil industry. Moreover, the sustainability issues especially in environmental aspects came from operational process in plantation [53]. Overall, this model is more efficient as an operational cost in oil palm plantation are eliminated and implicated in firm performance [4]. Therefore, the Commercial CPO mill can improve the quality of smallholder because this depends on the productivity of smallholders assisting in oil palm plantations. This model can allow to focused in improve the quality of smallholder as a challenge in Oil Palm Industry in Indonesia $[54,55]$.

\section{CONCLUSION}

The scope of this study is Indonesia CPO mill industry by using as a case study Riau province which had oil palm industry agglomeration representing $20.9 \%$ of the Indonesian oil palm plantation area. The research applied the qualitative analysis to assess the sustainable in Indonesia Commercial CPO mill based on ANP. It will gain an evaluation from various actor (academician, businessman, community and government) in palm oil industry and implicate the objective results. Key success factors of Indonesian commercial CPO mill were feedstock source availability from smallholders and CPO mill profitability considerations. Fair income distribution among stakeholders (people) and living environment (planet) consideration is also important for commercial CPO mill business in Indonesia (especially Riau). On the social side, commercial CPO mill establishment on location such as Riau province helps the local farmers through ease of doing transaction and profit sharing. The joint venture of smallholders and new players to build commercial CPO mill business is a vehicle of smallholder resurgence to enable inclusion in the palm oil economy. Conclusively in term of the triple bottom line, Indonesia commercial CPO mill business is sustainable with notice.

The notice for the palm oil business to be able to give an impact and address social and environmental problems can be done by creating shared value. Shared value is harmonious full pledge triple bottom line from academician, businessman, community and government perspectives which ranked profit $(53.05 \%)$, people $(23.75 \%)$ and planet $(23.19 \%)$. Commercial CPO mill business profit has a major impact upon people and planet. However, there is a common reason that business entities shall put profit priority over people and planet due to their liability to deploy some part of profit as resources to solve social and environmental issues. The future research can examine the sustainability of the palm oil industry from the smallholder perspectives. The reason is smallholders are one of the actors affected by the development of the palm oil industry. Moreover, the other analysis tools can be used to reinforce this research results.

\section{ACKNOWLEDGMENT}

This paper was a part of the research collaboration between PT. Deladelia Modal Insani (DMI Consulting Firm) with the School of Business, IPB University. The authors thank DMI Consulting Firm for the research funding. The authors would like to thank Ratna Dewita, Adis Imam Munandar, Amzul Rifin, Bukti Bagja, Khairul Huda, R. Rudy Irawan, Safwani, Suhailis, and Teten Effendi who generously shared their time and insights. The views expressed herein are those of the authors and do not necessarily reflect the views of the School of Business, IPB University or any other organization.

\section{REFERENCES}

[1] Pahan, I. (2016). Oil palm complete guidance: Agribusiness management from upstream to downstream. (in Bahasa Indonesia). Jakarta: Penebar Swadaya.

[2] Suroso, A., Tandra, H., Syaukat, Y., Najib, M. (2021). The issue in Indonesian palm oil stock decision making: Sustainable and risk criteria. Decision Science Letters, 10(3): 241-246. https://doi.org/10.5267/j.dsl.2021.4.001

[3] Rifin, A. (2010). Export competitiveness of Indonesia's palm oil product. Trends in Agriculture Economics, 3(1): 1-8. https://doi.org/10.1355/ae27-2b

[4] Suroso, A.I., Tandra, H., Najib, M., Syaukat, Y. (2020). Firm performance factors and efficiency of indonesian palm oil companies. Jurnal Manajemen dan Agribisnis, 17(3): 227-227. https://doi.org/10.17358/jma.17.3.227

[5] Suroso, A.I., Ramadhan, A. (2014). Structural path analysis of the influences from smallholder oil palm plantation toward household income: One aspect of egovernment initative. Advanced Science Letters, 20(1): 352-356. https://doi.org/10.1166/asl.2014.5317

[6] Tandra, H., Suroso, A., Najib, M., Syaukat, Y. (2021). The effect of COVID-19 in European union on the performance of Indonesian publicly listed palm oil companies. Accounting, 7(4): 801-808. https://doi.org/10.5267/j.ac.2021.2.004

[7] Agriculture Ministry. (2020). Tree crop estate statistics 2018 - 2020: Palm oil. Jakarta: Agriculture Ministry (in Bahasa Indonesia).

[8] Pahan, I., Gumbira-Sa'íd, E., Tambunan, M., Suroso, A.I. (2012). Development of palm oil industrial cluster in Indonesia. An analytic network process study. Saarbrücken: Lambert Academic Publishing.

[9] Tyson, A., Varkkey, H., Choiruzzad, S.A.B. (2018). Deconstructing the palm oil industry narrative in Indonesia: Evidence from Riau Province. Contemporary Southeast Asia, 40(3): 422-448.

[10] Purnomo, H., Okarda, B., Dermawan, A., Ilham, Q.P., Pacheco, P., Nurfatriani, F., Suhendang, E. (2020). Reconciling oil palm economic development and environmental conservation in Indonesia: A value chain dynamic approach. Forest Policy and Economics, 111: 102089. https://doi.org/10.1016/j.forpol.2020.102089 
[11] Susila, W.R. (2004). Contribution of oil palm industry to economic growth and poverty alleviation in Indonesia. Jurnal Litbang Pertanian, 23(3): 107-114.

[12] Pahan, I., Sa'id, E.G., Tambunan, M., Asmon, D., Suroso, A.I. (2011). The future of palm oil industrial cluster of Riau region. European Journal of Social Science, 24(3): 421-431.

[13] Elkington, J. (1997). Cannibals with forks-Triple bottom line of 21 st century business. Stoney Creek, CT: New Society Publisher.

[14] Wang, L., Lin, L. (2007). A methodology framework for the triple bottom line accounting and management of industry enterprises. International Journal of Production Research, 45(5): 1063-1088. https://doi.org/10.1080/00207540600635136

[15] Hammer, J., Pivo, G. (2016). The triple bottom line and sustainable economic development theory and practice. Economic Development Quarterly, 31(1): 25-36. https://doi.org/10.1177/0891242416674808

[16] United Nations General Assembly. (1987). Report of the world commission on environment and development: Our common future. Oslo, Norway: United Nations General Assembly, Development and International Cooperation: Environment.

[17] Emas, R. (2015). The concept of sustainable development: definition and defining principles. Brief for GSDR, 2015.

[18] Sterling, S. (2010). Learning for resilience, or the resilient learner? Towards a necessary reconciliation in a paradigm of sustainable education. Environmental Education $\quad$ Research, 16: 511-528. https://doi.org/10.1080/13504622.2010.505427

[19] Klarin, T. (2018). The concept of sustainable development: From its beginning to the contemporary issues. Zagreb International Review of Economics \& Business, 21(1): 67-94.

[20] Cahyandito, M.F., Ramadhan, R. (2015). Is converting shrub land to palm oil plantation worth it? -An ecosystem services analysis. Journal of Business and Retail Management Research, 10(1): 77-86. https://doi.org/10.24052/JBRMR/204

[21] Uldam, J., Vesteergard, A. (2015). Civic engagement and social media. Political participation beyond protest. London: Palgrave Macmillan.

[22] Manzo, K., Padfield, R., Varkkey, H. (2020). Envisioning tropical environments: Representations of peatlands in Malaysian media. Environment and Planning E: Nature and Space, 3(3): 857-884. https://doi.org/10.1177/2514848619880895

[23] McCarthy, J.F., Cramb, R. (2016). Conclusion, 442-464. In Cramb, R., McCarthy, J.F. (eds.). The oil palm complex: Smallholders, agribusiness and the state in Indonesia and Malaysia. Singapore: NUS Press.

[24] Porter, M.E., Kramer, M.R. (2011). Creating shared value. Harvard Business Review, 89/1-2 (January/February 2011): 62-77.

[25] Porter, M.E. (2013). The case for letting business solve social problems. Edinburgh: TEDGlobal, filmed Jun 2, 2013 (Video). Available at https://www.ted.com/talks/michael_porter_why_ business_can_be_good_at_solving_social_problems?lan guage $=$ en

[26] Oosterveer, P. (2015). Promoting sustainable palm oil: viewed from a global networks and flows perspective.
Journal of Cleaner Production, 107: 146-153.

[27] Saswattecha, K., Kroeze, C., Jawjit, W., Hein, L. (2015). Assessing the environmental impact of palm oil produced in Thailand. Journal of cleaner production, 100: 150-169.

[28] Rist, L., Feintrenie, L., Levang, P. (2010). The livelihood impacts of oil palm: Smallholders in Indonesia. Biodiversity and Conservation, 19(4): 1009-1024.

[29] Laurance, W.F., Koh, L.P., Butler, R., Sodhi, N.S., Bradshaw, C.J., Neidel, J.D., Mateo Vega, J. (2010). Improving the performance of the roundtable on sustainable palm oil for nature conservation. Conservation Biology, 24(2): 377-381.

[30] Afriyanti, D., Kroeze, C., Saad, A. (2016). Indonesia palm oil production without deforestation and peat conversion by 2050 . Science of the Total Environment, 557: 562-570.

[31] Carlson, K.M., Heilmayr, R., Gibbs, H.K., Noojipady, P., Burns, D.N., Morton, D.C., Kremen, C. (2018). Effect of oil palm sustainability certification on deforestation and fire in Indonesia. Proceedings of the National Academy of Sciences, 115(1): 121-126.

[32] Pacheco, P., Schoneveld, G., Dermawan, A., Komarudin, H., Djama, M. (2020). Governing sustainable palm oil supply: Disconnects, complementarities, and antagonisms between state regulations and private standards. Regulation \& Governance, 14(3): 568-598. https://doi.org/10.1111/rego.12220

[33] Agriculture Ministry. (2014). Palm oil commodity outlook. Jakarta: Agriculture Ministry (in Bahasa Indonesia). Available from: http://epublikasi.setjen.pertanian.go.id/download/file/11 1-outlook-kelapasawit-2014.

[34] James, B., Katie, G., Jitendra, M., Bharat, M. (2015). 'The big idea' the sustainable economy and the TBL (triple bottom line). Advances in Management, 8(1): 1-8.

[35] Ho, L., Taylor, M. (2007). An empirical analysis of triple bottom-line reporting and its determinants: Evidence from the United States and Japan. Journal of International Finance Management and Accounting, 18(2): $\quad 123-150 . \quad$ https://doi.org/10.1111/j.1467646X.2007.01010.x

[36] Arowoshegbe, A.O., Emmanuel, U., Atu, O.G. (2016). Sustainability and triple bottom line: An overview of two interrelated concepts. Igbinedion University Journal of Accounting, 2: 88-126.

[37] Saaty, T.L. (2008). Relative measurement and its generalization in decision making and pairwise comparisons are central in mathematics for the measurement of intangible factors the analytic hierarchy/network process. RACSAM-Revista de la Real Academia de Ciencias Exactas, Fisicasy Naturales. Serie A. Matematicas, 102(2): 251-318. https://doi.org/10.1007/BF03191825

[38] Lupo, T., Bellomo, E. (2020). A methodological framework based on a DANP model for evaluating the software quality in terms of usability: a preliminary investigation on mobile operating systems. Decision Science $\quad$ Letters, 9(4): 521-536. https://doi.org/10.5267/j.ds1.2020.8.005

[39] Saaty, T.L. (2001). Fundamentals of the analytic hierarchy process. In the Analytic Hierarchy Process in Natural Resource and Environmental Decision Making, $15-35$. 
[40] Sayyadi, R., Awasthi, A. (2020). An integrated approach based on system dynamics and ANP for evaluating sustainable transportation policies. International Journal of Systems Science: Operations and Logistics, 7(2): 182 191. https://doi.org/10.1080/23302674.2018.1554168

[41] Saaty, T.L., Vargas, L.G. (2006). Decision making with analytic network process. Economic, Political, Social and Technological Applications with Benefits, Opportunities, Cost and Risks. New York: Springer.

[42] Saaty, T.L. (2004). Decision making-the analytic hierarchy and network processes (AHP/ANP). Journal of Systems Science and Systems Engineering, 13(1): 1-35.

[43] Legendre, P. (2010). Coefficient of concordance. 164169. In N.J. Salkind (ed.). Encyclopedia of Research Design, 1: Los Angeles: SAGE Publications, Inc

[44] Cramb, R., McCarthy, J.F. (2016). The Oil Palm Complex: Smallholders, Agribusiness and the State in Indonesia and Malaysia. Singapore: NUS Press.

[45] Khan, M.H. (2010). Political settlement and the governance of growth-enhancing institutions. London: SOAS University of London (Unpublished). 139p. Available from: http://eprints.soas.ac.uk/9968/1/Political_Settlements_in ternet.pdf.

[46] Alhaddi, H. (2015). Triple bottom line and sustainability: A literature review. Business and Management Studies, 1(2): 6-10. https://doi.org/10.11114/bms.v1i2.752

[47] Bhattacharyya, A. (2014). Factors associated with the social and environmental reporting of Australian companies. Australasian Accounting, Business and Finance Journal, $\quad 8(1)$ : $25-50$. https://doi.org/10.14453/aabfj.v8i1.3

[48] Ijeoma, N.B., Oghoghomeh, T. (2014). Determining the contribution of corporate social responsibility on organizational performance. International Journal of Economics, Finance and Management Sciences, 2(1): 84-91. https://doi.org/10.11648/j.ijefm.20140201.19.

[49] Bohlmann, C., Krumbholz, L., Zacher, H. (2018). The triple bottom line and organizational attractiveness ratings: The role of pro-environmental attitude. Corporate Social Responsibility and Environmental Management, $\quad 25(5)$ : 912-919. https://doi.org/10.1002/csr.1507

[50] Zadek, S. (2007). The path to corporate responsibility. Harvard Business Review, 82/12 (December 2004):125132. https://doi.org/10.1007/978-3-540-70818-6 13

[51] Crane, A., Palazzo, G., Spence, L.J., Matten, D. (2014). Contesting the value of "creating shared value". California Management Review, 56(2): 130-153. https://doi.org/10.1525/cmr.2014.56.2.130

[52] Braccini, A.M., Margherita, E.G. (2019). Exploring organizational sustainability of industry 4.0 under the triple bottom line: The case of a manufacturing company. Sustainability, 11(1): https://doi.org/10.3390/su11010036

[53] Schrier-Uijl, A.P., Silvius, M., Parish, F., Lim, K.H., Rosediana, S., Anshari, G. (2013). Environmental and social impacts of oil palm cultivation on tropical peat: A scientific review. Roundtable of Sustainable Palm Oil, Kuala Lumpur, Malaysia, 131-168.

[54] Murdiyarso, D., Dewi, S., Lawrence D., Seymor, F. (2011). Indonesia's Forest Moratorium. Bogor: Center for International Forestry Research (CIFOR).

[55] Suroso, A.I., Pahan, I., Maesaroh, S.S. (2020). New Plantation Moratorium Policy and Smallholders Palm Oil Rejuvenation for Increasing Productivity of Indonesian Palm Oil. Jurnal Manajemen \& Agribisnis, 17(2): 138-138. https://doi.org/10.17358/jma.17.2.138 